DOI https://doi.org/10.30525/978-9934-26-180-0-48

\title{
УЧЕБНОЕ ПОСОБИЕ ПО НАУЧНОМУ СТИЛЮ РЕЧИ КАК СРЕДСТВО ФОРМИРОВАНИЯ ПРОФЕССИОНАЛЬНО-ОРИЕНТИРОВАННОЙ ЛИНГВИСТИЧЕСКОЙ КОМПЕТЕНТНОСТИ У ИНОСТРАННЫХ СТУДЕНТОВ
}

\author{
Варава C. B. \\ старший преподаватель кафедры языковой подготовки 2 \\ Учебно-научного института международного образования \\ Харьковский национальный университет имени В. Н. Каразина \\ г. Харьков, Украина
}

Известно, что приоритетной задачей обучения иностранцев на начальном этапе (т. е. на подготовительном факультете) является подготовка к дальнейшему обучению на русском языке на основных факультетах вузов, так как изучаемый язык для данного контингента студентов является не только языком общения, но и средством получения избранной профессии $[1 ; 2]$. К моменту поступления на первый курс студенты должны воспринимать на слух необходимый минимум лексикограмматических конструкций, лексических единиц терминологического характера, записывать полученную информацию в соответствии с правилами русского языка; строить на основе аудиально или визуально полученной информации грамматически верные монологические и диалогические высказывания. В процессе обучения необходимо учитывать коммуникативные потребности иностранных студентов [3; 4]. На первом курсе они должны слушать лекции (воспринимать, вычленять и записывать основную информацию), принимать участие в работе семинаров (строить монологические высказывания, вступать в диалог с преподавателем), читать учебную литературу по специальности и т. д. В связи с этим в процессе довузовского обучения у студентов должен быть сформирован необходимый уровень профессионально-ориентированной лингвистической компетентности, заложены основы языка будущей специальности в соответствии с профилем дальнейшего обучения. Проблемам преподавания иностранцам языка профессионального общения в связи с необходимостью учета профиля обучения студентов постоянно уделялось внимание на протяжении становления и развития методики РКИ [5: 6]. Однако описание способов формирования профессиональноориентированной лингвистической компетентности в настоящее время 182 
является недостаточно изученной проблемой и не имеет комплексного описания. Кроме того, современная практика преподавания выдвигает задачи разработки учебных материалов для обучения языку специальности иностранных студентов появляющихся в последнее время новых направлений подготовки. Актуальным становится разработка методики формирования профессионально-ориентированной лингвистической компетентности в русском языке у иностранных студентов и создание на базе этого узкопрофильных учебных пособий по русскому языку как иностранному с целью обучения языку будущей специальности $[7 ; 8]$.

Процесс формирования профессионально-ориентированной лингвистической компетентности на начальном этапе обучения иностранцев будет эффективным, если:

- обучение будет организовано с учетом узких профилей подготовки студентов;

- в процессе обучения будут использоваться профильноориентированные учебные пособия по русскому языку как иностранному;

- профильно-ориентированные учебные пособия будут служить средством формирования профессионально-ориентированной лингвистической компетентности в русском языке у иностранцев.

$\mathrm{B}$ качестве важных принципов описания лексики и грамматики с целью формирования профессионально-ориентированной лингвистической компетентности можно выделить:

- учет профиля обучения студентов при отборе лексического, грамматического и текстового материала $[9 ; 10 ; 11]$;

- минимизация изучаемого материала в учебных целях;

- специфическая интерпретация фактов иностранного языка;

- двуплановость описания (активный и пассивный аспекты);

- функциональность описания основных единиц языка;

- учет родного языка студентов;

- частотность употребления отобранных лингвистических единиц;

- принцип методической целесообразности (под этим в методике РКИ понимается соответствие отобранного материала и форм работы над ним речевым потребностям и возможностям студентов: необходимость, достаточность, доступность).

Учебники и учебные пособия, являющиеся основным средством обучения иностранным языкам, в том числе русского языка как иностранного (РКИ), должны создаваться в соответствии с основным методами преподавания РКИ, а именно - коммуникативным и сознательно-практическим. При этом должны быть также учтены: 
- практическая направленность целей обучения;

- функциональный подход к отбору и подаче языкового материала;

- ситуативно-тематическое представление языкового материала;

- изучение лексики и морфологии на синтаксической основе;

- концентрическое расположение учебного материала и выделение нескольких этапов обучения;

- учет родного языка учащихся.

Профильно-ориентированное учебное пособие должно содержать необходимый для формирования профессионально-ориентированной лингвистической компетентности лексико-грамматический и текстовой материал, а также систему упражнений для его отработки с учетом:

- направления подготовки студентов (профиля обучения);

- принципов межпредметной координации;

- принципа преемственности в обучении;

- соблюдения единого языкового режима в процессе обучения.

Сформулируем некоторые вопросы, нуждающиеся в дальнейшей разработке:

- необходимость изменения количества и перечня профилей обучения на этапе довузовской подготовки иностранцев;

- целесообразность выделения в рамках гуманитарного профиля более узких направлений подготовки студентов, а именно - разграничение гуманитарных, социальных и творческих специальностей;

- неуклонное соблюдение сложившихся и уже сформулированных принципов межпредметной координации (в другой терминологии междисциплинарных связей) в современных условиях при обучении новых категорий иностранцев;

- тщательный анализ специальных дисциплин, изучаемых студентами на первых курсах вузов по избранной специальности, и создание с учетом этого адекватных учебных планов и программ для новых направлений подготовки иностранных студентов на подготовительных факультетах;

- изучение особенностей подъязыка появившихся в последнее время профилей обучения (в частности, «изобразительное искусство и дизайн», «музыкальная культура и искусство», история; право и др.) и создание новых учебных пособий для обучения научному стилю речи и специальным дисциплинам;

- разработка технологии создания профильно-ориентированных учебных пособий для формирования профессионально ориентированной лингвистической компетентности в русском языке у иностранных студентов узкопрофильных специальностей. 
Для того чтобы проанализировать лингводидактические основы создания профильно-ориентированных учебных пособий по РКИ как средства формирования профессионально-ориентированной лингвистической компетентности у иностранных студентов, необходимо:

1) описать методические принципы отбора и презентации профессионально-ориентированного лексико-грамматического и синтаксического материала, который должен составить основу программы по научному стилю речи и лечь в основу профильно-ориентированного учебного пособия;

2) составить соответствующий профилю обучения лексический минимум, который должны освоить студенты к окончанию подготовительного факультета;

3) представить принципы отбора и презентации лексического и текстового материала в учебном пособии;

4) сформировать систему упражнений, предполагающую определенную последовательность их выполнения с учетом нарастания трудностей, а также охватывающую необходимые аспекты обучения.

В итоге должна быть выработана система требований, предъявляемых к созданию профильно-ориентированных учебных пособий, при помощи которых будет возможным сформировать профессионально-ориентированную лингвистическую компетентность в русском языке у иностранных студентов подготовительных факультетов вузов.

\section{Литература:}

1. История преподавания русского языка как иностранного в очерках и извлечениях: учебное пособие / Ред.-сост. А.Н. Щукин. М.: Филоматис, 2005. 176 с.

2. Капитонова Т. И., Московкин Л. В. Методика обучения русскому языку как иностранному на этапе предвузовской подготовки. СПб: Златоуст, 2006. 272 с.

3. Стародуб В.В. Актуальные проблемы обучения иностранных студентов русскому языку // Предвузовская подготовка иностранных студентов в СПбГПУ / Под ред. Д.Г. Арсеньева, О.В. Дороховой, А.И. Сурынига. - Серия «Проблемы обучения иностранных студентов». Вып. 3. СПб.: Изд-во Политехнического университета, 2005. С. 64-78.

4. Сурыгин А. И. Педагогическое проектирование системы предвузовской подготовки иностранных студентов. СПб.: Златоуст, 2001. 128 с.

5. Пассов Е. И., Н. Е. Кузовлева. Основы коммуникативной теории и технологии иноязычного образования: Методическое пособие для 
преподавателей русского языка как иностранного. - М.: Русский язык. Курсы, 2010. 568 с.

6. Митрофанова О.Д. Взаимодействие языковой и предметной компетенции в процессе обучения студентов-нефилологов // Современный учебник русского языка для иностранцев: Теоретические проблемы и прикладные аспекты: Международная научно-практическая конференция: 20-22 ноября 2002 г., Москва, МГУ им. М.В. Ломоносова: Тезисы. М.: МАКС Пресс, 2002. С. 109-110.

7. Варава С. В., Груцяк В. И. О необходимости создания государственного стандарта на довузовскую подготовку иностранцев по гуманитарным и творческим специальностям // Русский язык, литература, культура в школе и вузе. Киев, 2011. № 5. С. 52-55.

8. Варава С. В., Груцяк В. И. О необходимости создания учебных программ для довузовской подготовки иностранцев по гуманитарным и творческим специальностям // Русский язык в поликультурном мире. 2011: V Международная научно-практическая конференция (8-10 июня 2011 г., г. Ялта): Сб. науч. тр. Киев, 2012. С. 140-144.

9. Кутузова Г. И. Междисциплинарные связи в обучении иностранных студентов. СПб.: Изд-во Политехнич. ун-та, 2008. 378 с.

10. Кутузова Г. И. Подготовка иностранных студентов по русскому языку к учебной деятельности в техническом вузе и проблемы учебника / Г.И.Кутузова, В.В.Стародуб // Русское слово в мировой культуре: Материалы X Конгресса Международной ассоциации преподавателей русского языка и литературы. В 4-х т. - T. IV. Проблемы преподавания русского языка: обучение и контроль / Под ред. Н. А. Любимовой, Л.В.Московкина,Н.О.Рожковой, Е.Е.Юркова. СПб.: Политехника, 2003. C. 141-147.

11. Кутузова Г. И. Проблемы подготовки иностранных студентов к обучению в российских вузах на занятиях по русскому языку // Мир русского слова. 2004. № 4. С. 68-74. 